\title{
A MEASURING BOARD FOR SMALL FISHES
}

\author{
John K. Winther \\ Division of Fishes, University of Michigan Museum of Zoology \\ Ann Arbor, Michigan
}

NORTH AMERICAN FISHERY WORKERS do not have standard methods for describing or measuring lengths of fish. Ricker and Merriman (1945) reported eight different definitions of standard length, one of fork length, and two of total length in use by fishery biologists and systematic ichthyologists. At least four primary methods of measuring length are used: (1) ruler, (2) caliper, (3) divider, and (4) measuring board. Lack of uniformity appears to be due to differences in tradition and concepts of convenience.

It is probably futile to suggest, as has been done so frequently in the past, that one way to measure a fish is superior to another. Fishery biologists have learned to live with the length definitions of Lagler (1956) and the length conversions of Carlander (1953); many ichthyologists follow Hubbs and Lagler (1964).

Though it might seem that accuracy is equally important to the fishery scientist and the systematic scientist, Hubbs and Langler (1964, p. 24) wrote:

... Mer uring boards as commonly used in fishery investigations are hardly suitable for routine systematic work.

Evidently these authors believe that measuring boards are less accurate than the "smoothly working dividers" or a "dialreading caliper," which they recommend be used to measure fish.

Measuring boards were designed to facilitate the recording of length data from large samples, often under field condi-

Dr. Winter's present address: Humboldt State College, Arcata, California 95521.

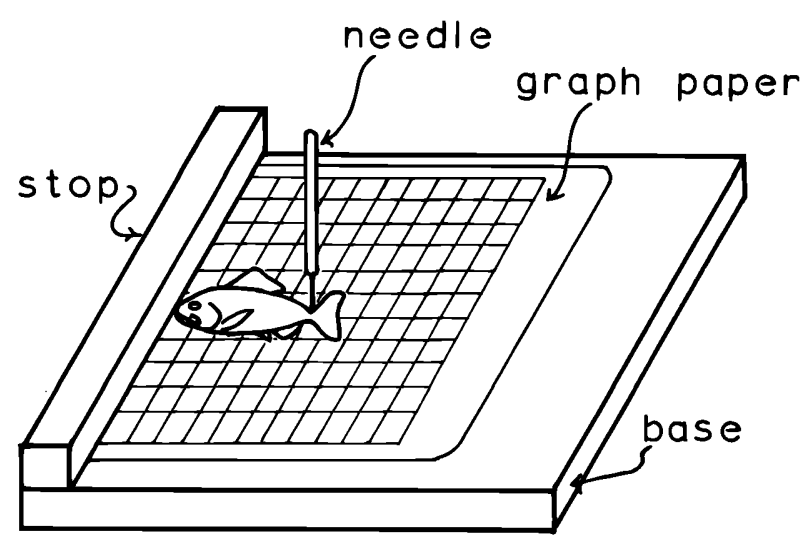

FIGURE 1.--Measuring board for small fishes.

tions. Increasing use of large samples by systematists appears to justify a reexamination of measuring boards and their utility as a tool. Several kinds of measuring boards and their uses for fish have been described (Joeris, 1959; Lopinot, 1964; Monan, 1963; and Shuster, 1954).

A simple measuring board (figure 1) is made of two pieces of soft wood and a sheet of 8.5 - by 11 -inch graph paper. The wood costs about 25 cents, the paper about 1 cent per sheet. Both English and metric systems in a variety of scales are available in bookshops and office-supply stores where graph paper is sold.

A fish is placed on a wet sheet of the paper (from which the left-hand margin has been cut) so that both the scale zeroline of the paper and the tip of the snout touch the stop. With a dissecting needle, a hole is punched through the paper at the point marking the posterior position of the length measurement desired. Depending 
TABLE 1.--Comparison of the means obtained for a 25-specimen sample of the sharpfin chubsucker, using three devices to measure standard length

\begin{tabular}{ccccc} 
& \multicolumn{4}{c}{ Mean standard length '(mm) } \\
\cline { 1 - 2 } Trial & $\begin{array}{c}\text { Measuring } \\
\text { board }\end{array}$ & Divider & Caliper \\
\cline { 5 - 6 } & 54.37 & 54.76 & 54.20 \\
Mean mean---- & 54.16 & 54.71 & 54.08 \\
\hline
\end{tabular}

on the abrasive qualities of the species and the length distribution of the sample, as many as 500 specimens per sheet of paper can be measured. I have done this with many small cyprinids and salmonids. After being dried on a flat surface to reduce wrinkling, the punched sheet is laid on a suitable backing, against which holes may be read directly to whatever degree of accuracy the original choice of scale permits.

Table 1 shows length data obtained by three methods: a measuring board (figure 1) and millimeter-paper, Original Lotter divider, and Helios vernier caliper. The same 25 specimens (30- to 74-millimeter S.L.) of the sharpfin chubsucker (Erimyzon tenuis, UMMZ 166162) were measured 3 times by each of the 3 methods (specimen, trial, and method randomized). No differences for the methods were detected at the 5-percent level of significance.

The scale on new, dry graph paper (National) is about +0.28 percent in error when compared to a steel ruler. If wetted and dried, the paper shrinks slightly, tending to correct this error. Burgner (1962) showed that shrinkage in preserved sockeye salmon (Oncorhynchus nerka) smolts is about 6 percent fork length after 5.5 months, and 80 percent of this occurs in the first 24 hours after death. Undoubtedly, differences in choice of preservative(s) and other facets of individual technique also affect measurement variation. Components of length-measurement variation due solely to use of a measuring board appear to be minor; thus the measuring technique described might be satisfactory for certain systematic applications.

\section{Acknowledgment}

Dr. Robert Rush Miller reviewed this manuscript and suggested improvements.

\section{Literature Cited}

\section{Burgner, Robert L.}

1962. Studies of red salmon smolts from Wood River lakes, Alaska. In: Studies of Alaska red salmon (S. $\bar{Y}$. Koo, ed.), University of Washington, Seattle, p. 257-258.

Carlander, Kenneth D.

1953. Handbook of freshwater fishery biology. W. C. Brown, Dubuque, Iowa, $429 \mathrm{p}$.

Hubbs, Carl L., and Karl F. Lagler.

1964. Fishes of the Great Lakes region. University of Michigan, Ann Arbor, $213 \mathrm{p}$.

Joeris, Leonard S.

1959. Rapid measurement of fish. Progressive Fish-Culturist, vol. 21, no. 4, p. 190-191.

Lagler, Karl F.

1956. Freshwater fishery biology. W. C. Brown, Dubuque, Iowa, $421 \mathrm{p}$.

Lopinot, A. C.

1964. A length-frequency measuring board for fish managers. Progressive Fish-Culturist, vol. 26, no. 3, p. 120 .

Monan, Gerald E.

1963. A device for measuring length of fish. Progressive Fish-Culturist, vol. 25, no. 2, p. 107-108.

Ricker, William E., and Daniel Merriman. 1945. On the methods of measuring fish. Copeia, no. 4, p. 184-191.

Shuster, Carl N., Jr.

1954. A method for recording measurements of certain molluscs, arthropods, and fishes. Progressive FishCulturist, vol. 16, no. 1, p. 39-40. 